\title{
A survey on the development of Islamic higher education in Indonesia: an epistemological review
}

\author{
Sa'adi
}

Postgraduate Program State Institute for Islamic Studies (STAIN) Salatiga, Indonesia

E-mail:saadidr@yahoo.com

\begin{abstract}
Social changes, development and advancement of humans' culture influence education as inseparable aspect of human life. In line with Islamic higher education many thinkers proposed their ideas of how to formulate its appropriate epistemological background in different views. There are some notable persons for this field, such as Iqbal, Fazlur Rahman, Afzalur Rahman, Al-Faruqi which to some extent parallel or influence Indonesian thinkers' such as Mukti Ali, Harun Nasution, Cak Nur, Amin Abdullah, etc. Some are still at the level of speculative thought, while others have applied their ideas in educational institutions, like Amin Abdullah and Imam Suprayoga.
\end{abstract}

Perubahan sosial, perkembangan dan kemajuan kebudayaan umat manusia memengaruhi pendidikan yang merupakan bidang yang tak terpisahkan dari kehidupan manusia itu sendiri. Dalam hal pendidikan tinggi Islam, para pemikir mengajukan berbagai gagasan mereka tentang bagaimana merumuskan dasardasar epistemologinya yang paling tepat. Ada beberapa tokoh pemikir penting yang perlu dicatat (dari luar negeri) dalam hal ini seperti Iqbal, Fazlur Rahman, 
Afzalur Rahman, al-Faruqi, yang dalam batas tertentu secara paralel atau memengaruhi para pemikir Indonesia seperti Mukti Ali, Harun Nasution, Cak Nur, Amin Abdullah dan Imam Suprayoga. Sebagian dari pemikir tersebut masih pada dataran pemikiran spekulatif, sementara yang lain sudah mengaktualisasikannya dalam implementasi kelembagaan pendidikan tinggi Islam, seperti Amin Abdullah dan Imam Suprayoga.

Keywords: Epistemology; Higher education; Institution; Curriculum

\section{Introduction}

Islamic education in Indonesia especially that of higher institution is still in progress to formulate its appropriate philosophical background. Educational epistemology is considered as the most fundamental aspect in this endeavor because it will influence the quality of its curriculum, process, and output as well.

This paper is inspired by academic and social problems faced by Indonesian Islamic higher education (PTAI). Academically Islamic higher education is still trying to find its suitable epistemological bases for Indonesian context as a plural nation to face future challenges. Traditional Islamic epistemology as being applied up to present time such as in the old fashion models of jadalì, burhānì, bayānỉ and 'irfānì as apllied in kalām, tașawwuf, falsafa and fiqh is indicated to be inappropriate any longer with the modern scientific and technological advancement. This unavoidably influences the quality of institutional and curriculum development of Islamic higher education itself, and the quality of their alumnus as well. As such Islamic studies at higher learning institutes are still limited by normative and traditional methodology, separable from the empirical and real social life especially in Indonesian context.

As social problems, Indonesian Islamic higher education is often indicated to achieve low quality if compared from other national or 
international universities. Many people -including Indonesian Muslimsstill consider it 'the $3^{\text {rd' }}$ class higher education, through weak selection in the admission process that make Muslim students themselves less proud to be its member. It is also indicated to have very limited budget and facilities from the government, so that it is difficult for the institution to conduct qualified researches, scientific activities and fulfill complete facilities and learning sources which need much finance and sources. Consequently only very limited people groups tend to be interested to select it for their higher education.

\section{Review of epistemological development of Islamic higher educa- tion}

Traditionally the epistemology of classical Islamic sciences as noted by Muhammad 'Abid al-Jabiri, ${ }^{1}$ is bayānì (popularly applied in fiqh, Islamic jurisprudence), jadali (popularly apllied in kalām, theology) burhānì (popularly applied in philosophy) and 'irfänì (commonly applied in tașawwuf, mysticism). In practice, they go in parallel and also have not interconnected, and even some times blame and negate each other such as fiqh (Islamic jurisprudence) was ever 'the enemy' of tașawwuf (Sufism). Falsafa and kalām (theology) had no relation with tașawwuf or fiqh.

This phenomena is unavoidable because historically those sciences were produced in Arab cultural background which are rooted from their pluralistic-atomistic ontological world view, which believe in the plurality of realities but each has no relation with others, such as in law of cause and effect. As such masters (scholars, ulama) of fiqh, lugha, falsafa, kalām and tașawwuf developed their own sciences isolated from oth-

1 Muhammad 'Abid al-Jabiri, Bunyah al-'Aql al-'Arabï , Beirut: al-Markaz al-Thaqafi al-'Arabi, $1991,38$. 
ers' perspectives. These later were widely disseminated through Islamic educational institutions which had negative effect in the development of Islamic education itself, including in Indonesia.

In later development as reaction, Suhrawardi al-Maqtul criticized this unbeneficial situation by proposing his pupolar approach of falsafa ishrāqiyya (illumination) which tried to integrate "irfānì and burhānì approaches, that is by purifying heart through kashf or intuition ${ }^{2}$ and at the same time seriously exploring the power of human reason to acquire the Divine knowledge (al-'ulūm wa al-ma'ārif al-ilāhiya). Then Mulla Sadra ${ }^{3}$ completed the idea by developing his view namely alfalsafa al-muta'alliya (the transcendental epistemology) which tried to integrate the three models: the textual approach (bayānì), the spiritual-mystical approach ('irfānì ), and the rational approach (burhānì ). Inspite of their superiorities, these later epistemologies (al-ishrāqiyya and al-falsafa al-muta'alliya) do not touch the empirical and sociological dimensions of human life, because they are still purely speculative in nature and isolated from socio-cultural contexts.

It was Muhammad Iqbal -the $19^{\text {th }}$ century greatest Islamic thinker from India- who firstly criticized such epistemological crises through his doctorate dissertation entitled The Development of Metaphysic in Persia. He argued that the methodology of tașawwuf (mysticism) was partly influenced by non-Islamic elements, especially that of from Hindustan. This, to some extent, also happened in other classical Islamic sciences such as falsafa (philosophy), kalām (theology) and fiqh (jurisprudence) which were also influenced - at least as reactionespecially by Greek (rationalism and idealism), Rome (Christianity), Persia (Zoroaster) and India (Hinduism and Buddhism) world views. Such

\footnotetext{
2 Murtadha Muttahari, Tema-Tema Filsafat Islam, Bandung: Mizan, 1993, 43.

3 Jalaludin Rahmat, "Hikmah Muta'aliyah, Filsafat Pasca Ibnu Rusyd", al-Hikmah (1993), 78.
} 
thoughts were widely and massively taught at traditional Islamic institutions through literature and preachers. These consequently made confusions among the students of Islam (especially that of in Nusantara and Java santri) and unable to produce encyclopedic Muslim scholars such as in the early period of Islam. This made them left behind the western people almost in all aspects of life and colonized for several centuries.

Fazlur Rahman from Pakistan proposed his double movement theory in understanding the Islamic teaching between text which is normative, revealed and permanent, and the context which is sociological, historical and changeable in nature. ${ }^{4}$ Based on this idea, consequently Islamic education epistemology must correlate those two dimensions of Islam towards creative and dynamic movement and changes. The writer thinks that Rahman's epistemology of knowledge is pluralistic in nature. The text of revelation is permanent and pure (mabni) as the supreme source of Islam and must be understood and interpreted creatively and dynamically according to development of human civilization. In this case the interpretation is changeable ( $\left.m u^{\prime} r a b\right)$ according to contexts and local, regional and even international situations. In Indonesian context this idea is closely parallel with Muhammadiyah doctrines of tarjih and tajdid which was popularly campaigned by Ahmad Dahlan by establishing modern Islamic educational institutions in Indonesia.

Ismail Raji al-Faruqi was the most significant figure in the development of Islamic epistemology in 1980s. Inspired by the principles of tawhild ${ }^{5}$ he campaigned 'Islamization' of sciences. It was as the reac-

\footnotetext{
48.

${ }^{4}$ Fazlur Rahman, Neomodernisme Islam, trans. Taufik Adnan Amal, Bandung: Mizan, 1993,

${ }^{5}$ See Isma'il Raji al-Faruqi, The Cultural Atlas of Islam, London: Macmillan Publishing Co., 1986.
} 
tion of positivistic paradgim domination which is free from divine values in its character, so that it fails to build ethical and humanistic science and technology. And western modern and secular civilization is the direct result of positivistic epistemology. Nietzsche, Karl Marx, Charles Darwin and Sigmund Freud are the most prominent thinkers and scientists with atheistic scientific theories based on positivistic paradigm. The tragic twice Word Wars which caused massive destructions of human civilization clearly proved the failure of positivism.

The project of al-Faruqi's Islamization of sciences got wide response in Islamic campuses in the Muslim world including in Indonesia. Some supported, but many criticized it. In Indonesia, the discourse was still popular up to 1990s in higher Islamic education. The emergence of sciences such as Islamic education, Islamic psychology, Islamic banking and sharia economics are based on Islamic epistemology inspired by the al-Faruqi's epistemology in Islamization of science. Up to the present time these studies are so popular in recent development of Indonesian Islamic higher education (PTAI), some place them as their faculty, department, study program or as curricular subject either at undergraduate, postgraduate or doctorate programs.

Afzalur Rahman (1981), a 'fundamentalist' Muslim scholar from Pakistan developed the idea of tawhild (unity) as the main principle of Islam. It ranges from the unity of God (tawhịid rubūbiya and ilāhiya), then goes down lower to the formulation of the unity of universe (tawhid kawnî). From here, then he developed the idea of unity of humanity (tawhìd insānî) as the bases of unity of human personality (tawhìid shakhsil). Finally he formulated the epistemology of unity of all sciences and knowledge (tawhïl al-'ulūm) in his specific term of Quranic sciences. All knowledge and sciences which have been achieved by humans along history are essentially one dimension of the same body of 
the unlimited God's knowledge. According to this epistemology, there is no separation and division of knowledge and sciences as religious or secular ones. As its implication the curriculum applied in Islamic educational institutions make no separation of religious and secular knowledge and sciences. This is what might be called Islamic integrated curriculum. It was formally practiced in the regime of President Ziaul Haq of Pakistan.

Historically Islamic educational institutions in Indonesia ranged from pesantren (traditional informal boarding institution), madrasa (Islamic eduacational institution) formally under The Ministry of Religious Affairs and sekolah (formal institution under Ministry of National Education) and then developed through Institute of Islamic Studies (PTAI namely IAIN) ${ }^{6}$ and recently STAIN (in 1997) and UIN (from 2000s). So far in practice the methodology of Islamic religious education is majorly still based on traditional epistemology in the forms of religious subjects isolated from the modern scientific, technological and contemporary social development.

Epistemological crises in Indonesian Islamic higher education became the focus of Mukti Ali's attention soon after he has work placed as minister of religious affair in 1967. Islamic epistemology at that time was merely focused on traditional religious sciences (al-'ulūm al-diniya such as fiqh, kalām, tașawwuf, akhlaq and so on). This is also well known as old mandate of PTAI. As senior professor of Islamic studies at State Institute of Islamic Studies (IAIN) of Sunan Kalijaga, he found the phenomena that the methodology of Islamic studies at Islamic higher education in Indonesia was too traditional (in serious backwardness) and separated (unfamiliar, isolated) from modern social and natural sciences and humanities. To bridge the gap, he then proposed his

\footnotetext{
${ }^{6}$ See Karel Steenbrink, Pesantren, Madrasah, Sekolah, Jakarta: LP3ES, 1984.
} 
popular concept of Islamic studies epistemology, namely scientific cum doctrinair.7 Religion can be viewed from different perspectives. It is esoterically a matter of metaphysical sacred doctrines which is based on belief or faith and acceptance. But at the same time it can also be studied objectively and scientifically from its exoteric dimensions such as in social performance and individuals' behaviors of religious

He instructed to include modern sciences such as sociology, history, Western people. philosophy, psychology, anthropology, statistics, comparative religion, Occidentalism, research methodology and English etc., in the curriculum of IAIN. The methodology of Islamic studies must be injected with 'new epistemology' which is rich of scientific, rational and objective perspectives.

He even once proposed that to achieve the progress of Islamic studies, teaching foreign languages (English and Arabic) at Islamic higher education should apply all in one system approach. He then started to send some lecturers of IAIN to continue their study in Western countries such as at McGill University (Canada) from which he graduated for his doctorate degree and also to Chicago University (USA). The policy was then continued by Munawir Sjadzali as he has work placed at the ministry of religious affairs in 1980s. More lecturers of IAIN were sent to Western universities such as Leiden (Nederland) and McGill (Canada) for Master and Doctorate degrees or just to conduct research. He also invited some professors of Islamic studies from there to lecture at IAIN. According to Munawir Sjadzali, there are three important points to be promoted in higher Islamic education; reinterpretation, reactualization and revitalization ${ }^{8}$ of Islamic doctrines scientifically.

\footnotetext{
${ }^{7}$ Read Mukti Ali, Alam Pikiran Islam Modern di India dan Pakistan, Bandung: Mizan, 1992.

${ }^{8}$ For further reading see Munawir Sjadzali, Islam, Realitas Baru dan Orientasi Masa Depan Bangsa, Jakarta: UI Press, 1993.
} 
Harun Nasution was a notable Indonesian Muslim scholar in 1980s for his rationalist Islamic epistemology. He promoted the rational views of Mu'tazilite theology. Through his master piece: Islam Ditinjau dari Berbagai Aspeknya (1980), Teologi Muktazilah (1990) and Islam Rasional (1995) he campaigned his rational epistemology. He stated that Islam is in line with modern scientific principles. Up to 1990s his book of Islam Ditinjau dari Berbagai Aspeknya still became the main source of Islamic study methodology taught for all students at all Indonesian Islamic higher education. In this period the epistemology of Islamic higher institution grew widely as it is popular with wider mandate with the scoup of dirāsat islāmiyat (Islamic studies).

Nurcholis Madjid was a prominent thinker in the epistemological development in Islamic higher education. He was a professor of Islamic studies at IAIN Syarif Hidayatullah, Jakarta. As he graduated from Chicago University he started to launch his rational, objective, historical and sociological views for the development of methodology of Islamic study. He disseminated his critical ideas through his monumental writing untitled Khasanah Intelektual Islam (1986) He stated that Islam has two dimensions, namely doctrine and civilization (this term then becomes the title of his book Islam, Doktrin dan Peradaban (1995). While Indonesian Muslims majorly still view that Islam is merely one entity.

Based on that epistemology, Cak Nur then proposed his concept of secularization (in sociological perspective, not secularism in philosophical meaning as it is widely misunderstood and also reacted negatively by the public). This concept divides the ontology of realities as sacred and profane. For him the Sacreed is God (His revelation as the source of authentic Islamic teaching which is accepted by belief and faith), and the profane (worldly objects) are all objects except Him which can be 
studied rationally, objectively and scientifically. Tașawwuf, kalām, falsafa and fiqh are profane as human interpretation of the sacred texts, so that these are possible to be studied scientifically. To disseminate his ideas Cak Nur then founded Paramadina University in Jakarta which opens post graduate program for Islamic studies.

The 1990s and 2000s era signs a new development of epistemology at Islamic higher education in Indonesia. It was pioneered by $\mathrm{M}$. Amin Abdullah —-the former student of Mukti Ali- at IAIN Sunan Kalijaga. Partly inspired by Rahman's idea, through his successive books entitled: Falsafa Kalām (1995), Studi Islam, Normativitas atau Historisitas (1996) and Islamic Studies di Perguruan Tinggi Pendekatan IntegratifInterkonektif (2006), he introduces his epistemological views of Islamic studies at Islamic higher education.

He firstly argued that Islamic studies have two dimensions, namely normative and historical. The normative Islam is written in the holly Quran and the sayings of prophet Muhammad. These are authentic and permanent texts (mabni ). While the historical Islam is the interpretation of texts, this can be in the forms of intellectual, spiritual, judicial, social and cultural performance. These are changeable (qābil li altaghyïr wa al-niqāsh) because of being limited by space, time, persons, cultural factors, etc.. Quranic interpretation and thoughts in fiqh, tașawwuf, falsafa, kalām and different Muslims' traditions are historical phenomena that are not permanent. They can be studied objectively, rationally and scientifically through psychology, sociology and anthropology by hermeneutic approach (al-qirā'a al-muntija). Amin Abdullah criticizes those who believe or consider them sacreed as taqdis al-fikr al-Islāmì.

Epistemologically, Amin Abdullah criticizes the classical Islamic sciences methodology as 'Abid Jabiri notes, namely bayānì, burhānī, jadalì 
and 'irfānî. This methodology is still widely applied in Indonesian Islamic higher education. According to him, it is not relevant any longer to apply them strictly in this post-modern era in which sciences are developing in interconnectedness and integrative. There are three possibilities of the application of this traditional methodology in education: parallel, longitudinal and cycle or spiral models. Each has serious consequences. But Amin Abdullah seems to prefer spiral model since it has least risks. As a philosophic doctor, he strongly supports the application of hermeneutic approach in Islamic text studies in Islamic higher education interconnected with modern sciences ${ }^{9}$, and spread his 'liberal' thoughts through publications and forums.

Amin Abdullah responds positively the post-modernism discourse in 1990s which exposes some new ideas, such as deconstruction of grand theories, relativism and pluralism (then expands to multiculturalism and inclusivism). As response to these ideas, he has campaigned his great ideas of epistemology in the form of interconnection and integration of sciences in Islamic studies. He then promotes his epistemological formulation namely 'spider web theory'.10 This was institutionally realized by opening the interdisciplinary Islamic studies in social works for post graduate program, launching the campaign of inter-religious dialogues and later up graded the status of his institution, namely Institute of Islamic Studies (IAIN) to be State Islamic University (UIN) —at the same time with IAIN Syarif Hidayatullah of Jakarta led by Professor Azyumardi Azra - which opens not only conventional religious faculties of ('ulūm diniya) such as Da 'wa, Ușūl al-din, Adab, Tarbiya and Sharia, but also social, natural, humanities, medical and technical faculties inte-

\footnotetext{
${ }^{9}$ M. Amin Abdullah, Islamic Studies di Perguruan Tinggi, Pendekatan Integratif-Interkonektif, Yogyakarta: Pustaka Pelajar, 2006.

${ }^{10}$ See further M. Amin Abdullah, Islamic Studies di Perguruan Tinggi, Pendekatan IntegratifInterkonektif, Yogyakarta: Pustaka Pelajar, 2006.
} 
grated and interconnected with religious education. This is then successively followed by other IAINs such as in Pekan Baru, Malang, Makasar, Bandung, etc.. As a new mandate, Dirāsat Islāmiyat is more fundamental at this institution based on rational, objective and scientific approaches, rather than merely tafaqquh fi al-din.

Last but not least, Imam Suprayoga from malang is the most popular recent figure among the PTAIs for his notable success to upgrade his higher institution status as a frog jump, from State College for Islamic Studies (STAIN) to be State Islamic University (UIN). He develops deductively his epistemology through a theory of science tree. According to him, revelation (the holy Quran and Prophet tradition) is the root of all knowledge and sciences, from which grow different religious, natural, technical, medical, social and humanities sciences. To realize his project, he cooperates with the IDB (Islamic Development Bank) to finance the development of the university campus. He is invited to many universities to deliver his epistemological ideas and successful experiences to lead his university.

He wonders why the name of faculties at Islamic institutes are Da'wa, Ușūl al-din, Adab, Tarbiya and Sharia, while the Holy Quran never mentions such names as its themes. The Quran names its süra (chapter, theme) with al-Baqara, al-An'ām, al-Naml (zoology), Ālu 'Imrān, Luqmān, Maryam, Banī Isrāîl, Hūd, Muḥammad, Ibrāhīm, Nūḥ, Saba', al-Balad, al-Nās and al-Insān which are closely related to the study of history, anthropology and sociology, al-Shams, al-Layl, al-Qamar, alFajr, al-Burūj, al-Falaq, al-Ṭāriq and al-Ḍuhā which are closely related to the study of astronomy. These names of suras are more closely related with modern sciences and technology rather than with such traditional religious faculties. As implementation of his concept, he builds houses for the teaching staffs and dormitory for students in the cam- 
pus complex to create religious culture. He continuously promotes intensive Arabic (and English) teaching and learning the holly Quran by heart among lecturers and students. Tafaqquh fi al-din in his institution is more fundamental based on deep spituality, wide knowledge and strong moral, rather than merely Dirāsat Islāmiyat which does not strongly build comprehensive Islamic personal character.

\section{Educational implication}

As previously described that the curriculum of Islamic higher education and pesantren (traditional Islamic educational institution) majorly adopt epistemology of bayānì, burhānī, jadali and 'irfānī. Even falsafa is still disliked study - if not totally forbidened - among certain Muslim scholars (ulama) in Indonesia. And this influences the way of thinking among its graduates in that they are closed in mind, truth claimer, being unable to catch and adapt with modern scientific and technological development and to anticipate the future challenges. As such Muslims are left behind (past time oriented), backwardness in science and technology. This was historically proved that for some centuries they were colonized by Europeans.

According to the writer, the project of al-Faruqi's Islamization of sciences can be applied with modification. Knowledge and science have their ontological, epistemological and axiological levels. Tawhid as scientific ontology and Islamic ethics as axiological dimension are no problem, but epistemologically wahy as the source of knowledge especially humanities, social, natural and technical sciences can be too deductive which will hindrance the progress of science itself. Wahy must be considered as basic or 'raw material of' information, its motivator and source or spirit of knowledge. 
What was provoked by Mukti Ali through his epistemological concept of scientific cum doctrinair methodology can be developed in Islamic higher education, because this can open students' mind to be critical and objective in viewing religious teachings related to modern sciences. But it is still in its early development that needs to be continued.

Rational Islam as promoted by Harun Nasution's epistemology can be appreciated critically, since Indonesian Muslims are so plural. Humans have psychological dimensions, such as nafs, 'aql, qalb, rūḥ and fitra. These must be developed proportionally and in balance, not just 'aql (reason). Maximazing 'aql is appropriate for natural exploration and technology.

The concept of secularization as provoked by Nurcholis Madjid should be carefully discussed and clarified especially for students, because it is sensitive issue. There must be clear meaning between secularism as philosophical concept and secularization as sociological discourse. This will have serious impact in the curriculum and educational institution. To consider God or revelation as the only sacred can possibly degrade some religious symbols in Islam. If the sacred is the Ultimate Being it may be acceptable, but it is philosophical discourse, not sociological one. For Muslims, Islamic education itself is sacred mission.

Interconnection, interlink and integration of approaches in Islamic Studies as promoted by Amin Abdullah epistemology of 'spider web'11 is considered to be fairly comprehensive and accommodative to be developed in higher Islamic education, since they have multi-perspectives and dimensions. It can be supported by Noeng Muhadjir's metaphysic realism epistemology which covers dimensions of sensual,

${ }^{11}$ M. Amin Abdullah, Islamic Studies di Perguruan Tinggi, Pendekatan Integratif-Interkonektif, Yogyakarta: Pustaka Pelajar, 2006. 
logical, ethical, spiritual and transcendental empiricism. ${ }^{12}$ The lack and weakness of positivistic and phenomenological paradigms can be corrected and compeleted in this metaphysic realism epistemology. As such in practice for example, the study of figh can be connected with sociology, anthropology, psychology, geography, medical science, history and language, etc., so as to uṣūl fiqh, tafsìr, hadith, kalām, falsafa and tașawwuf. This methodology is very relevant to educate students to be Muslim scientists.

Imam Suprayogo's epistemology of 'science tree' is symphatic enough to appreciate. It is very relevant to educate students to be ulama (Muslim scholars) having deep spirituality, because the knowledge is rooted and started from belief and faith in God. But this possibly tends to fundamentalist views and apologetic because of its deductive methods. This had happened in European Church in the early renaissance that rejected scientific finding that was contradictory with the bible text.

It may be wise to synthesize those two epistemological views. One is deductive view (Imam Suprayogo's), while the other is inductive (Amin Abdullah's). It is interesting to note that International Conference of Islamic Education in Mecca (1977) formulated the sources of knowledge, namely the revealed and the acquired knowledge. This can be starting point for the discussion to find solution of these contradictory views.

The epistemology of metaphysic realism of Carl Popper which is then 'islamized' by Noeng Muhadjir to be integrated with Amin Abdullah's and Imam Suprayoga' epistemologies are significant contribution to be

12 Please read Noeng Muhadjir, Metodologi Penelitian Kualitattif, Yogyakarta: Rake Sarasin, 1992. 
adopted to find relevant solution for the development of Islamic higher education epistemology.

The writer proposes his specific epistemology for higher Islamic education which is rooted from the three roles and status of humans on this earth, namely 'ibāda (worshiping God), khilāfa (vicegerent of God) and mu'àmala (human relation). 'Ibāda (worshiping Allah) is the supreme goal of human creation on this globe. All humans actions and behaviors are ideally devoted to Him. While khilăfa is the realization of vicegerency on the earth to make it useful and prosperous for realizing to worship Him. Mu'ämala refers to realization of human interrelation since humans are created interdependently ( $\min$ 'alaq) with other fellow men.

The implication of this epistemology in setting educational curriculum is in the form of three angles of interrelation of religious knowledge (for the mission of 'ibāda), natural and technical sciences (for implementation of khiläfa) and social and humanities sciences (for application of mu'ämala), in which each side strengthens and enlightens others simultaneously. By so doing, all knowledge and sciences in the curriculum have the same position, importance and mission supporting each other. As an example, teaching Arabic is related to fiqh, geography and economy or politics such as using Arabic news paper, etc.

\section{Closure}

In brief here is the summary of epistemological development survey in Islamic higher education in Indonesia. Traditional Islamic epistemology as noted by Muhammad 'Abid al-Jabiri is bayānì (fiqh), jadali (kalām), burhānī (falsafa) and 'irfānī (tașawwuf). This is thought to be less sufficient to meet the modern life because they are purely speculated and too spiritual in nature and do not touched empirical and sociological 
problems of life. Muhammad Iqbal through his Reconstruction of Religious Thoughts tried to purify Islamic knowledge from non-Islamic elements such Greek, Persia, India and Rome (Latin). That was based on the findings of his dissertation entitled The Metaphysical development in Persia.

Isma'il Raji al-Faruqi campaigned his idea of the Islamization of sciences. It has positive results in creating Islamic sciences such as Islamic banking, Islamic Psychology, sharia economics, and Islamic education. His project is widely applied in Indonesian universities.

Fazlur Rahman (rationalist Muslim scholar) of Pakistan proposed double movement epistemology in comprehending Islamic teaching between text (revelation) and context (interpretation and application). Afzalur Rahman ('fundamentalist' Muslim scholar) of Pakistan sets his epistemology of education based on tawhild (unity of God, universe, humanity, human's personality and sciences).

In Indonesia, Mukti Ali proposed idea of scientific cum doctrine epistemology. The curriculum of PTAI must be enriched with modern sciences such as psychology, philosophy, comparative religion, sociology, anthropology, English, etc. Besides that, Harun Nasution promoted rational Islam epistemology in Islamic studies. Islam must be studied from different perspectives through a subject namely methodology of Islamic studies to all students of all PTAI. Nurcholis Madjid introduced his concept of doctrine and civilization dimensions of Islam which contains the concept of secularization (in sociological term, sacred and profane), doctrine (permanent) and civilization (changeable) in Islam.

M. Amin Abdullah promotes the normative and historical Islam, hermeneutic approach in Islamic studies, and interconnection-interlink and integration approaches in Islamic studies. He successfully up grades 
his institution from IAIN to be UIN. His counterpart Imam Suprayoga provokes his epistemology of sciences tree. Knowledge is rooted from the revelation (belief), then grows some branches of knowledge. He is successful to upgrade his institution from STAIN to be UIN.

The writer proposes the three dimensions of human roles in life, those are as 'ibāda, khilāfa and mu'ämala. They are as the bases of Islamic educational epistemology which can be developed in the form of three angles of religious, natural and social/humanities sciences, in which each side strengthen and enlighten others simultaneously.

\section{Bibliography}

Abdullah, M. Amin. Falsafah Kalam. Yogyakarta: Pustaka Pelajar, 1994. Abdullah, M. Amin. Studi Agama, Normativitas atau Historisitas? Yogyakarta: Pustaka Pelajar, 1996.

Abdullah, M. Amin. Islamic Studies di Perguruan Tinggi, Pendekatan Integratif-Interkonektif. Yogyakarta: Pustaka Pelajar, 2006.

Ali, Mukti. Alam Pikiran Islam Modern di India dan Pakistan. Bandung: Mizan, 1992.

Al-Faruqi, Isma'il Raji. The Cultural Atlas of Islam. London: Macmillan Publishing Co., 1986.

Al-Jabiri, Muhammad 'Abid. Bunyah al-'Aql al-'Arabï. Beirut: al-Markaz al-Thaqafi al-'Arabi, 1991.

Madjid, Nurkholis. Islam Doktrin dan Peradaban. Jakarta: Rajawali Press, 1995.

Muhadjir, Noeng. Metodologi Penelitian Kualitatif. Yogyakarta, Rake Sarasin, 1992.

Muttahhari, Murtadha. Tema-Tema Filsafat Islam. Bandung: Mizan, 1993. 
Nasution, Harun. Islam Ditinjau dari Pelbagai Aspeknya. Jakarta: UI Press, 1986.

Rahman, Afzalur. Quranic Sciences. Singapura: Pustaka Nasional PTE LTD, 1981.

Rahman, Fazlur. Islamic Methology in History. New Delhi: Adam Publisher, 1994.

Rahman, Fazlur. Neomodernisme Islam. transl. Taufik Adnan Amal. Bandung: Mizan, 1993.

Rahmat, Jalaludin, "Hikmah Muta'aliyah, Filsafat Pasca Ibnu Rusyd", al-Hikmah (1993).

Sadjzali, Munawir. Islam, Realitas Baru dan Orientasi Masa Depan bangsa. Jakarta: UI Press, 1993.

Saiyidain. Percikan filsafat Iqbal Mengenai Pendidikan. Bandung: CV. Diponegoro, 1986.

Steenbrink, Karel. Pesantren, Madrasah, Sekolah. Jakarta: LP3ES, 1984. 